\title{
Wellness School Assessment Tool Version 3.0: An Updated Quantitative Measure of Written School Wellness Policies
}

\author{
Marlene B. Schwartz, PhD ${ }^{1}$; Elizabeth Piekarz-Porter, JD²; Margaret A. Read, MA ${ }^{1}$; \\ Jamie F. Chriqui, PhD, MHS $^{2}$
}

\begin{abstract}
Accessible Version: www.cdc.gov/pcd/issues/2020/19_0373.htm
Suggested citation for this article: Schwartz MB, Piekarz-Porter E, Read MA, Chriqui JF. Wellness School Assessment Tool Version 3.0: An Updated Quantitative Measure of Written School Wellness Policies. Prev Chronic Dis 2020;17:190373. DOI: https:/ /doi.org/10.5888/pcd17.190373.
\end{abstract}

\section{PEER REVIEWED}

\section{Summary}

What is already known on this topic?

Current federal regulations require most school districts to consider evidence-based strategies to address student wellness and write policies that outline practices related to school food, nutrition, and physical activity.

\section{What is added by this report?}

Previous versions of a free online tool, the Wellness School Assessment Tool (www.WellSAT.org), have been used over the past decade to provide a quantitative, reliable assessment of the comprehensiveness and strength of these policies for administrators, researchers, and other stakeholders.

\section{What are the implications for public health practice?}

This article describes how the measure was updated in 2018 to WellSAT 3.0 in response to changes in the federal law, research, and expert feedback.

\section{Abstract}

Schools play an important role in promoting student wellness. As directed by the Healthy Hunger-Free Kids Act, the US Department of Agriculture updated the requirements for written school wellness policies in 2016. The WellSAT (Wellness School Assessment Tool) is an online tool that provides a quantitative score for wellness policy comprehensiveness and strength. The WellSAT has been updated 3 times over the past decade to remain current with federal law and best practices. In this article, we describe the process of updating to WellSAT 3.0. The steps included: review- ing the language of each item linked to a federal provision; adding and deleting items based on frequencies from the National Wellness Policy Study and the empirical support for specific policies; gathering feedback from a survey of experts $(\mathrm{N}=77)$ about best practices and measure usability; and establishing intercoder reliability in a national sample $(\mathrm{N}=50)$ of policies. We conclude with recommendations and guidance for the use of WellSAT 3.0.

\section{Background}

Over the past 15 years, the role of schools in promoting wellness has been in the spotlight (1-3). Policies and regulations have been implemented at the state level (4) and federal level, most recently through the Healthy Hunger-Free Kids Act of 2010 (HHFKA) (5-8). In addition, since 2006, local district wellness policies (hereafter School Wellness Policies [SWPs]) have been required in all school districts participating in federal child nutrition programs $(9,10)$.

Originally, SWPs were required to include goals for nutrition education and physical activity to promote student wellness; nutritional guidelines for all foods available on each school campus during the school day; an assurance that reimbursable school meals follow federal law; a plan for measuring policy implementation; and the involvement of parents, students, the school food authority, school board, school administrators, and the public in the development of the policy (9). However, the HHFKA (8) required the US Department of Agriculture (USDA) to update its regulations concerning SWPs, and new regulations were put into effect in 2016 (7). Currently, SWPs must also ensure that school districts review and consider evidence-based strategies to promote student wellness; comply with federal competitive food nutrition standards (ie, Smart Snacks [6]) for all foods sold on campus during the school day; prohibit marketing of all foods and beverages that do not meet Smart Snacks standards; permit all stakeholders to participate in policy development, implementation, review, and updates; report annually to the community about policy content, imple- 
mentation, and updates; complete triennial assessments on compliance, alignment with model policies, and progress toward goals; and designate one or more officials as responsible for school-level compliance with the policy.

\section{Original assessment measure for SWPs}

To support the empirical study of SWPs, a 96-item quantitative measure was published in 2009 (11). Policy items were identified by reviewing model policies, district self-evaluation tools, state checklists, and state policy classification systems by the National Cancer Institute (12-14). A rubric was developed to assess how completely each item was addressed, and each item was assigned a corresponding score: topic not addressed at all, score $=0$; topic mentioned in a general manner or as part of a recommendation, score $=1$; topic addressed in a specific manner or as part of a requirement, score $=2$. The tool provided 2 summary scores: comprehensiveness, the percentage of items that received a 1 or 2 ; and strength, the percentage of items that received a 2 . This scoring distinguished districts with strong policies that require or prohibit a practice (eg, "Teachers are prohibited from using food as a reward") while also acknowledging that districts may take an incremental approach to policy change by beginning with aspirational recommendations (eg, "We recommend that teachers use nonfood rewards").

\section{Measure evolution}

Over time, this measure was adapted to meet needs in the field. First, Chriqui and colleagues expanded it for the largest, ongoing nationwide assessment of SWPs. This endeavor originated in the Bridging the Gap research program and continued in the National Wellness Policy Study (NWPS) $(2,15)$. To date, more than 5,000 districts nationally have been coded to provide reliable data on the content and strength of SWPs over time $(2,10)$.

Second, in 2010 a national advisory group shortened the measure, named it the WellSAT (Wellness School Assessment Tool), and placed it on a free website, www.wellsat.org. WellSAT 1.0 had 50 items and 6 subscales: nutrition education (NE); standards for USDA school meals (SM); nutrition standards for competitive and other foods and beverages (NS); physical education and physical activity (PEPA); wellness promotion and marketing (WPM); and implementation, evaluation, and communication (IEC). After coding, the user receives 1) each item's score, 2) the comprehensiveness and strength scores for each subscale, and 3) the comprehensiveness and strength scores for the whole policy. Users can code multiple policies and download scores into an Excel file. Since its launch, the website has been accessed more than 100,000 times, and nearly 7,000 registered users have coded more than 9,000 policies from all 50 states and Washington, DC.
In 2014, WellSAT 2.0 was released to reflect the strengthened school meal standards of the HHFKA (5). After the final wellness policy rule requirements for school year 2017-18 were released $(6,7,16)$, the measure and website were updated to version 3.0. This article describes the update and guidance for users of the tool. This study was determined to be exempt from institutional review board approval.

\section{Updating to WellSAT Version 3.0}

To revise the measure, the research team reviewed the language of each item inked to a federal provision; examined item frequencies from the NWPS; reviewed the empirical support for specific policies that were under consideration for inclusion or removal; gathered feedback from a survey of experts about best practices and measure usability; and established intercoder reliability. Table 1 lists the 19 WellSAT 3.0 variables that are based on a federal requirement, and Table 2 provides the final 67 WellSAT 3.0 items, the 12 WellSAT 2.0 items that were removed, and the reasons for the changes. The final measure is available at www.wellsat.org.

\section{Updates related to federal provisions}

First, we edited and added items to reflect updated federal language $(6,7,16)$ : NE1, SM1, SM8, NS1, NS6, NS7, NS9, WPM7, IEC2, IEC3, IEC4, IEC5, IEC6, IEC7. The item concerning privacy for students receiving free/reduced lunch (SM3) was also updated by noting that it is a federal requirement.

\section{NWPS data and current evidence}

In our second step, we examined frequency data from the 2014-2015 wave of the NWPS. This wave of 496 district policies was collected from a nationally representative sample of school food authorities that completed the director survey of the USDA's School Nutrition and Meal Cost Study (10). We used frequency data to inform decisions about adding and removing items. Items that rarely appeared in policies, were no longer relevant because of changes in the federal law, or were not considered best practices or evidence-based were considered for removal. Concurrently, we considered adding emerging topics and additional policies assessed in the NWPS.

All removed items are listed in Table 2. "School meals meet standards that are more stringent than those required by USDA" was originally created because meal standards were not in alignment with the Dietary Guidelines for Americans; however, this item is no longer necessary because of updated federal regulations (5). "Students leaving school during lunch periods" reflected concerns that students on open campuses may be more likely to eat fast

The opinions expressed by authors contributing to this journal do not necessarily reflect the opinions of the U.S. Department of Health and Human Services, the Public Health Service, the Centers for Disease Control and Prevention, or the authors' affiliated institutions. 
food, but closed campus provisions appear infrequently in the NWPS. "Addresses school meal environment" was written to capture cafeteria features, including adequate space and a clean, pleasant environment; however, it is not in the NWPS, and the team determined that the lack of specificity made the item difficult to interpret. "Nutrition information for school meals (eg, calories, saturated fat, sodium, sugar) is available to students and parents" was important before the implementation of the updated nutrition standards (5) but is no longer a priority. "Recess (when offered) is scheduled before lunch in elementary schools" was originally included because it was considered a best practice; however, it was removed because of inconclusive evidence (22,23). "Foods and beverages containing nonnutritive sweeteners in high school" was removed because of low frequency in the NWPS and current scientific guidance (24). "Teacher-student ratio for physical education classes" was removed because of low frequency in the NWPS data set. "Physical education waiver requirements for K-12 students" was also removed owing to low frequency and because waiver provisions are typically governed by state law rather than district policies. "Staff involvement in physical activity opportunities at all schools" was removed owing to low frequency in the NWPS and a new, broader item was added to address staff wellness (WPM2). Finally, "District provides physical activity training for all teachers" and "Staff not modeling unhealthy eating/drinking behaviors" were removed to be consistent with NWPS. The item about positive staff role modeling (WPM1) was retained.

NWPS items were reviewed for inclusion in WellSAT 3.0 if they were present in coded policies and supported as best practices. "Nutrition education integrated into subjects beyond health education" (NE6) was added because it increases opportunities for nutrition education and appears frequently NWPS policies. "How to handle feeding children with unpaid meal balances without stigmatizing them" (SM4) was added because of increasing awareness of problematic practices and advocacy efforts to protect children (20). Because all foods sold during the school day must meet Smart Snacks standards, 3 new venue-specific items were added to be consistent with NWPS: à la carte (NS3), vending machines (NS4), and school stores (NS5). "Physical education promotes a physically active lifestyle" (PEPA3) (25) was added because it is present in $70 \%$ of NWPS policies, and "The establishment of an ongoing school building-level wellness committee" (IEC8) was added because it has been identified as a best practice (21).

\section{Expert survey}

The next step was to gather feedback about current best practices and measure usability from tool users and experts on school wellness policies. In April 2018, an online survey was emailed to recently active registered WellSAT 2.0 users $(n=\sim 1,000)$; the Cen- ters for Disease Control and Prevention (CDC) Nutrition and Obesity Policy Research and Evaluation Network School Wellness Workgroup $(n=146)$; the Voices for Healthy Kids Nutrition and Physical Activity in Schools Coalition, led by Alliance for a Healthier Generation $(n=25)$; and experts from CDC $(n=2)$ and Action for Healthy Kids $(n=2)$. Some people received the survey more than once because of membership in multiple groups.

In the first part of the survey, we provided the revised list of items under consideration for each subscale and asked respondents to rank the importance of each item as low, medium, or high. There was an open response field for comments and suggested wording modifications next to each item. At the end of each subscale section, we asked, "Please comment on the items as a whole with regard to the policies associated with [name of subscale]. Collectively, do the items capture the range of policy considerations? Are there items you recommend adding or deleting?" The second set of questions included the scoring criteria for each item to achieve a 2 (ie, strong policy) and asked respondents to indicate if the criteria should be "weaker," "stronger," or if "it's just right." Each question also included a field for comments or wording modifications.

The survey was open for 1 month and was completed by 77 expert users. Respondents were from individual school districts (38\%); universities (21\%); state/local departments of education or health (14\%); national advocacy organizations (18\%); state/local advocacy organizations (4\%); and national government (4\%).

Across all items, an average of $8 \%$ of respondents rated items as low importance, $25 \%$ rated items as medium importance, and $67 \%$ rated items as high importance. The only 2 items rated "low importance" by more than $20 \%$ of respondents concerned school gardens and Farm to School activities. In the comments, respondents said that school gardens are not feasible for all schools and coders may not understand which activities are part of "Farm to School." To respond, the school garden item was removed and instead, gardens were included as an example in a new item on nutrition education addressing agriculture and the food system (NE8). A second new item addressed purchasing local foods for the school meal program (SM10). To help coders, there is a watering can icon by these items and links to the National Farm to School Network website to highlight these core Farm to School elements (19).

The experts recognized the importance of comprehensive physical activity but suggested that instead of 1 item referencing CDC's Comprehensive School Physical Activity Program (CSPAP) by name (26), there should be items for each component. Thus, the 2.0 CSPAP question was removed and a running person icon identifies the component items: physical education (PEPA1); family

The opinions expressed by authors contributing to this journal do not necessarily reflect the opinions of the U.S. Department of Health and Human Services, the Public Health Service, the Centers for Disease Control and Prevention, or the authors' affiliated institutions. 
and community engagement (PEPA11); physical activity before and after school (PEPA12); and physical activity breaks during school (PEPA14) (26). The fifth CSPAP component concerns staff; however, the 2.0 item, "Staff involvement in physical activity opportunities at all schools," was found in only $18 \%$ of NWPS polices. Furthermore, experts recommended folding this into a broader staff wellness item. Therefore, the NWPS item, "Strategies to address employee wellness" (WPM2) replaced it.

The feedback on the " 2 " scoring criteria indicated that most experts felt the guidance should stay the same. On average across all items, $9 \%$ of the experts thought guidance should be "weaker," $12 \%$ felt it should be "stronger," and 79\% said it was "just right." Additional comments from the expert survey informed wording changes and clarifications (Table 2). Experts suggested clearly distinguishing items required by federal law, so they are marked with a Capitol building icon, the label "federal requirement," and exact quotes of federal language with the scoring guidance.

\section{Intercoder reliability}

Our final step was to use the NWPS database of policies collected in the 2014-2015 school year (15) to draw a national sample of 72 school district policies that had been recently updated. From this sample, 50 school districts were chosen if their policy had one or more indicators of incorporating recent USDA rules: 1) Smart Snacks appeared within the text of the policy, 2) water availability at lunch appeared within the text, or 3) the policy achieved high comprehensiveness scores.

Per NWPS protocol, we used internet research with telephone or email follow-up to the superintendent's office to obtain the 2017-2018 school year policy documents for the 50 identified districts. Because 4 districts were nonresponsive, the next 4 districts identified using the selection criteria were substituted. The SWPs included the board-adopted wellness policy and the associated administrative guidelines, rules, and regulations. Written school wellness policies often list references to other related district policies, state, or federal laws within the text of the wellness policy to communicate that these additional regulations are also recognized by the district; therefore, we also included any additional policies that were incorporated by reference (eg, food service policies, state physical and health education standards). All documents were coded by 2 trained analysts using standard NWPS methods $(2,4,10)$.

Two coders independently coded the policies and assessed reliability in groups of $5 \mathrm{SWPs}$. The percentage agreement on the first 2 batches was $73 \%$ and $76 \%, \kappa=0.56$ and $\kappa=0.60$, respectively. The primary coder (E.P.) identified problematic items and wrote additional coding guidance. The percentage agreement on the next
2 sets of 5 polices was $82 \%$ and $83 \%, \kappa==0.71$ and $\kappa=0.72$, respectively. Remaining confusion centered on nutrition standards and how district language should be applied to each venue, including fundraisers. To clarify the correct application of Smart Snacks, new language was added to introduce the nutrition standards section. The final batch of 5 districts achieved $92 \%$ agreement, $\kappa=$ 0.88 . Additional examples were added to the coding guidance to clarify lingering issues. The remaining districts were coded using a consensus coding approach.

\section{WellSAT 3.0 Data and Uses}

Table 3 contains descriptive statistics for each item in the full sample of policies $(\mathrm{N}=50)$. All items were written into at least 1 policy in the sample. The mean comprehensiveness score across all categories of the 54 policies indicated that, on average, districts address more than half of the items on the measure, and the mean strength score of 33 means that only one-third of items include strong, definitive language.

WellSAT 3.0 has multiple uses, including self-evaluation by district wellness committees to comply with the requirement to compare their own policy with model policies and best practices (7). Similarly, state agencies can use it to complement their triennial reviews of SWPs, as required by the USDA (16). State agencies may also find WellSAT useful in providing technical assistance to school districts and tracking environmental policy changes. For example, New York State has used WellSAT to support a cohort of school districts (27), and evaluators in Arizona have used it as one of their SNAP-Ed policy strategies (28).

Although the summary scores are between 0 and 100, they should not be translated into letter grades. The coding reflects the strongest versions of policies, setting the bar to avoid a ceiling effect and help districts strive for excellence. To interpret scores, a stepped interpretation strategy is recommended. First, examine only the items that are noted as federal requirements, and ensure that they are present in the written policy. Next, evaluate each subscale comprehensiveness and strength score. If comprehensiveness is much higher than strength, consider using stronger, more specific language to clarify the expectation of the policy. If comprehensiveness scores are low, pick a subscale consistent with district priorities and consider adding new policies.

\section{Comparing scores over time}

The WellSAT has changed substantially since its inception in 2006. The first version emphasized going beyond federal requirements in multiple domains, including setting strong nutrition standards for school meals and foods and beverages sold outside of meals. The HHFKA now requires many of these practices, so

The opinions expressed by authors contributing to this journal do not necessarily reflect the opinions of the U.S. Department of Health and Human Services, the Public Health Service, the Centers for Disease Control and Prevention, or the authors' affiliated institutions. 
WellSAT 3.0 items assess compliance with federal regulations. However, this measure also promotes further progress, such as extending strong nutrition standards to food sold or served after the school day.

\section{Limitations}

The primary benefit of updating this measure is to reflect changes in federal law and current evidence-based and expertrecommended best practices. However, districts that used WellSAT 2.0 will not be able to track improvements over time. The WellSAT 2.0 tool is available on the website for those districts. Furthermore, the 50 test policies selected were chosen because they were comprehensive, so scores should not be interpreted as nationally representative. However, the results were consistent with the nationally representative NWPS finding that policies address many topics in an aspirational, nonbinding manner (10). Finally, some of the strong scores are due to state laws, not language specific to the SWP (10).

In conclusion, schools are a critical setting for health promotion, and strong SWPs are a key strategy to ensure consistent implementation of best practices. National surveillance is needed, particularly during school year 2020-2021 after the triennial assessments are required. Future research should evaluate the impact of the HHFKA wellness policies and regulations on local policies, practices, and ultimately student and staff health outcomes.

\section{Acknowledgments}

Funding for this study was provided by Healthy Eating Research (grant no. 74396), a national program of the Robert Wood Johnson Foundation (principal investigator, M.B.S.), and from the US Department of Agriculture School Wellness Policy cooperative agreement (grant no. USDA-FNS-OPS-SWP-15-IL-01) (principal investigator J.F.C.). The study sponsors did not have any role in study design, collection, analysis, or interpretation of data; writing the report; or the decision to submit the report for publication. The authors thank Leann Hennessey for assistance with data collection and Julien Leider for assistance with data analysis. We also are grateful to those who provided feedback on the WellSAT 3.0 tool as part of the survey process and as members of our advisory committee.

\section{Author Information}

Corresponding Author: Marlene B. Schwartz, PhD, Professor, Department of Human Development and Family Sciences, Director, Rudd Center for Food Policy and Obesity, University of Connecticut, 1 Constitution Plaza, Suite 600, Hartford, CT 06103. Telephone: 860-380-1211. Email: Marlene.schwartz@uconn.edu.

Author Affiliations: ${ }^{1}$ Rudd Center for Food Policy and Obesity, University of Connecticut, Hartford, Connecticut. ${ }^{2}$ Institute for Health Research and Policy, School of Public Health, University of Illinois at Chicago, Chicago, Illinois.

\section{References}

1. Committee on Accelerating Progress in Obesity Prevention. Accelerating progress in obesity prevention: solving the weight of the nation. Washington (DC): Institute of Medicine of the National Academies; 2012.

2. Piekarz E, Schermbeck R, Young SK, Leider J, Ziemann M, Chriqui JF. School district wellness policies: evaluating progress and potential for improving children's health eight years after the federal mandate, school years 2006-07 through 2013-14. Volume 4. Chicago (IL): Bridging the Gap Program and the National Wellness Policy Study, Institute for Health Research and Policy, University of Illinois at Chicago; 2016.

3. Story M, Nanney MS, Schwartz MB. Schools and obesity prevention: creating school environments and policies to promote healthy eating and physical activity. Milbank Q 2009; 87(1):71-100.

4. Piekarz-Porter E, Chriqui JF, Schermbeck RM, Leider J, Lin $\mathrm{W}$. The active roles states have played in helping to transform the school wellness environment through policy, school years 2006-07 through 2014-15. Chicago (IL): Bridging the Gap Program and the National Wellness Policy Study, Institute for Health Research and Policy, University of Illinois at Chicago; 2017.

5. Nutrition standards in the National School Lunch and School Breakfast Programs. Fed Regist 2012;4088.

6. National School Lunch Program and School Breakfast Program. Nutrition standards for all foods sold in school as required by the Healthy, Hunger-Free Kids Act of 2010, final rule. Fed Regist 2016;50132.

7. Local school wellness policy implementation under the Healthy, Hunger-Free Kids Act of 2010, final rule. 81 Federal Register $\$ 501512016$.

8. Healthy, Hunger-Free Kids Act of 2010. PL 111-296; 124 Stat $\S 31832010$ (111th Congress).

The opinions expressed by authors contributing to this journal do not necessarily reflect the opinions of the U.S. Department of Health and Human Services, the Public Health Service, the Centers for Disease Control and Prevention, or the authors' affiliated institutions. 
9. Child Nutrition and WIC Reauthorization Act of 2004. PL $\S 108-265 ; 118$ Stat 729 (2004) (108th Congress) section 204.

10. Piekarz-Porter E, Schermbeck RM, Leider J, Young SK, Chriqui JF. Working on wellness: how aligned are district wellness policies with the soon-to-be implemented federal wellness policy requirements? Chicago (IL): National Wellness Policy Study, Institute for Health Research and Policy, University of Illinois at Chicago; 2017.

11. Schwartz MB, Lund AE, Grow HM, McDonnell E, Probart C, Samuelson A, et al. A comprehensive coding system to measure the quality of school wellness policies. J Am Diet Assoc 2009;109(7):1256-62.

12. Model Local School Wellness Policies. Model School We $11 \mathrm{ness}$ Poli c i s we b s t e. ht t p :// www.schoolwellnesspolicies.org/modelpolicy.html. Accessed April 18, 2019.

13. Mâsse LC, Chriqui JF, Igoe JF, Atienza AA, Kruger J, Kohl HW 3d, et al. Development of a Physical Education-Related State Policy Classification System (PERSPCS). Am J Prev Med 2007;33(4,Suppl):S264-76.

14. Mâsse LC, Frosh MM, Chriqui JF, Yaroch AL, Agurs-Collins T, Blanck HM, et al. Development of a School NutritionEnvironment State Policy Classification System (SNESPCS). Am J Prev Med 2007;33(4,Suppl):S277-91.

15. Research products: National Wellness Policy Study. Chicago (IL): University of Illinois at Chicago Institute for Health Research and Policy. https://www.ihrp.uic.edu/content/ research-products-national-wellness-policy-study. Accessed March, 25, 2020.

16. Administrative reviews in the school nutrition programs. Final rule 81. Fed Regist 2016;50170.

17. Professional standards for state and local school nutrition programs personnel as required by the Healthy, Hunger-Free Kids Act of 2010, final rule. 80 Federal Register $\$ 11077$ (2015).

18. National School Lunch Act Program Requirements. 42 USCS $\S 1758$. Public Law 1975;94-105.

19. What is Farm to School? National Farm to School Network website. http://www.farmtoschool.org/about/what-is-farm-toschool. Accessed April 21, 2019.

20. Food Research Action Center. Establishing unpaid meal fee policies: best practices to ensure access and prevent stigma. http://frac.org/wp-content/uploads/frac-unpaid-meal-feespolicy-guide.pdf. Updated January 2018. Accessed April 21, 2019.

21. Profili E, Rubio DS, Lane HG, Jaspers LH, Lopes MS, Black $\mathrm{MM}$, et al. School wellness team best practices to promote wellness policy implementation. Prev Med 2017;101:34-7.
22. Fenton K, Rosen NJ, Wakimoto P, Patterson T, Goldstein LH, Ritchie LD. Eat lunch first or play first? Inconsistent associations with fruit and vegetable consumption in elementary school. J Acad Nutr Diet 2015;115(4):585-92.

23. Strohbehn CH, Strohbehn GW, Lanningham-Foster L, Litchfield RA, Scheidel C, Delger P. ( 2016). Impacts of scheduling recess before lunch in elementary schools: A case study approach of plate waste and perceived behaviors. J Child Nutr Manage 2016;40(1).

24. Gardner C, Wylie-Rosett J, Gidding SS, Steffen LM, Johnson RK, Reader D, et al.; American Heart Association Nutrition Committee of the Council on Nutrition, Physical Activity and Metabolism, Council on Arteriosclerosis, Thrombosis and Vascular Biology, Council on Cardiovascular Disease in the Young, and the American Diabetes Association. Nonnutritive sweeteners: current use and health perspectives: a scientific statement from the American Heart Association and the American Diabetes Association. Circulation 2012; 126(4):509-19.

25. National Standards for K-12 Physical Education. SHAPE America. https://www.shapeamerica.org/standards/pe/. Accessed April 18, 2019.

26. Centers for Disease Control and Prevention. Comprehensive school physical activity programs: a guide for schools. US Department of Health and Human Services; 2013. https:// www.cdc.gov/healthyschools/professional_development/elearning/CSPAP/page03.html. Accessed April 21, 2019.

27. Brissette I, Wales K, O'Connell M. Evaluating the Wellness School Assessment Tool for use in public health practice to improve school nutrition and physical education policies in New York. J Sch Health 2013;83(11):757-62.

28. University of Arizona. School Health, AZ Health Zone SNAPEd Evaluation. https://nutritioneval.arizona.edu/school-health. Accessed April 21, 2019.

The opinions expressed by authors contributing to this journal do not necessarily reflect the opinions of the U.S. Department of Health and Human Services, the Public Health Service, the Centers for Disease Control and Prevention, or the authors' affiliated institutions. 


\section{Tables}

Table 1. Federal Wellness Policy Required Elements and Corresponding WellSAT 3.0 Variable

\section{Required Element of School Wellness Policies (7)}

Specific goals for nutrition promotion and education, physical activity, and other school-based activities that promote student wellness. In developing these goals, local education agencies must review and consider evidence-based strategies and techniques; $\S 210.31(\mathrm{c})(1)$

Nutrition guidelines for all foods and beverages available on each school campus during the school day that are consistent with federal school meal standards and Smart Snacks in School nutrition standards; §210.31 (c)(3)

Nutrition standards for all foods and beverages provided, but not sold, to students during the school day; §210.31 (c)(2)

Policies for food and beverage marketing on school campus during the school day of only those foods and beverages that meet Smart Snacks in School; §210.31 (c)(3)(iii)

A description of the manner in which stakeholders (parents, students, teachers, school food authority, teachers of physical education, school health professionals, school board, school administrators, and the public) are provided an opportunity to participate in policy development, implementation, review, and update; §210.31 (c)(5)

A requirement that the district inform the public about the content and implementation of the local wellness policy, and make the policy and any updates to the policy available to the public on an annual basis; $\$ 210.31$ (d)(2)

A requirement that at least once every 3 years, the district assess schools' compliance with the local wellness policy, and make the assessment results available to the public; §210.31 (e)(2)

A requirement that the district make appropriate updates or modifications to the local wellness policy, based on the triennial assessment; §210.31 (e)(3)

Identification of one or more district and/or school officials as wellness policy leadership who are responsible for the implementation and oversight of the wellness policy to ensure each school's compliance; $§ 210.31$ (e)(1)

\section{Healthy, Hunger Free Kids Act of 2010 (8)}

Schools must make potable water available to children at no charge in the place where lunches are served during the meal service; $\S 203$

\section{Professional Standards for State and Local School Nutrition Programs Personnel (17)}

Annual training requirements include $12 \mathrm{~h}$ for new and current directors, $10 \mathrm{~h}$ for new and current managers, $6 \mathrm{~h}$ for new and current $\mathrm{SM} 9$ staff; $\S 210.30(\mathrm{e})$

National School Lunch Act (18)

School food authorities must ensure that a child's eligibility status is not disclosed at any point in the process of providing free or reduced-price meals; $§ 1758(\mathrm{~b})(10)$

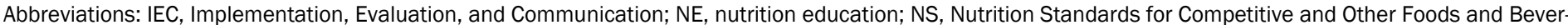
ages; SM, Standards for USDA School Meals; WellSAT, Wellness School Assessment Tool; WPM, Wellness Promotion and Marketing.

${ }^{a}$ This variable assesses elementary school policies; the federal language is general and does not specify school level.

The opinions expressed by authors contributing to this journal do not necessarily reflect the opinions of the U.S. Department of Health and Human Services, the Public Health Service, the Centers for Disease Control and Prevention, or the authors' affiliated institutions. 
Table 2. Final WellSAT 3.0 Items, Removed 2.0 Items, and Reasons for Changes

\begin{tabular}{|c|c|c|c|}
\hline \multicolumn{2}{|c|}{ WellSAT 3.0 Item } & Change & Reason for Change \\
\hline \multicolumn{4}{|c|}{ Nutrition Education (NE) } \\
\hline NE1 & $\begin{array}{l}\text { Federal requirement: includes goals for nutrition education that are designed } \\
\text { to promote student wellness }\end{array}$ & $\begin{array}{l}\text { Wording revised from } 2.0 \text { NE1 to } \\
\text { reflect federal language. }\end{array}$ & Reflect final rule language \\
\hline NE2 & $\begin{array}{l}\text { Nutrition education teaches skills that are behavior focused, interactive, and } \\
\text { participatory }\end{array}$ & Wording revised from 2.0 NE6 & Feedback from expert survey \\
\hline NE3 & $\begin{array}{l}\text { All elementary school students receive sequential and comprehensive } \\
\text { nutrition education }\end{array}$ & $\begin{array}{l}\text { Wording revised from } 2.0 \text { NE2 to } \\
\text { add "sequential and } \\
\text { comprehensive" }\end{array}$ & Feedback from expert survey \\
\hline NE4 & $\begin{array}{l}\text { All middle school students receive sequential and comprehensive nutrition } \\
\text { education }\end{array}$ & $\begin{array}{l}\text { Wording revised from } 2.0 \text { NE3 to } \\
\text { add "sequential and } \\
\text { comprehensive" }\end{array}$ & Feedback from expert survey \\
\hline NE5 & $\begin{array}{l}\text { All high school students receive sequential and comprehensive nutrition } \\
\text { education }\end{array}$ & $\begin{array}{l}\text { Wording revised from } 2.0 \text { NE4 to } \\
\text { add "sequential and } \\
\text { comprehensive" }\end{array}$ & Feedback from expert survey \\
\hline NE6 & Nutrition education is integrated into other subjects beyond health education & New item & $\begin{array}{l}\text { NWPS found } 25 \% \text { weak and } 35 \% \\
\text { strong policies }\end{array}$ \\
\hline NE7 & Nutrition education is linked with the school food environment & Wording revised from 2.0 NE5 & Feedback from expert survey \\
\hline NE8 & $\begin{array}{l}\text { Farm to School item: Nutrition education addresses agriculture and the food } \\
\text { system }\end{array}$ & New item & $\begin{array}{l}\text { Feedback from expert survey and } \\
\text { Farm to School best practices (19) }\end{array}$ \\
\hline \multicolumn{4}{|c|}{ Standards for USDA School Meals (SM) } \\
\hline SM1 & $\begin{array}{l}\text { Federal requirement: assures compliance with USDA nutrition standards for } \\
\text { reimbursable school meals. }\end{array}$ & $\begin{array}{l}\text { Wording revised from } 2.0 \text { SM2 to } \\
\text { add "assures" }\end{array}$ & Reflect final rule language \\
\hline SM2 & Addresses access to the USDA School Breakfast Program & \multicolumn{2}{|l|}{ No change } \\
\hline SM3 & $\begin{array}{l}\text { Federal requirement: district takes steps to protect the privacy of students } \\
\text { who qualify for free or reduced-priced meals }\end{array}$ & $\begin{array}{l}\text { Wording revised from } 2.0 \mathrm{SM} 4 \text { to } \\
\text { note this is a federal requirement }\end{array}$ & It is a federal requirement \\
\hline SM4 & $\begin{array}{l}\text { Addresses how to handle feeding children with unpaid meal balances without } \\
\text { stigmatizing them }\end{array}$ & New item & $\begin{array}{l}\text { Reflects current issue in the field } \\
(20)\end{array}$ \\
\hline SM5 & $\begin{array}{l}\text { Specifies how families are provided information about determining eligibility } \\
\text { for free/reduced-price meals }\end{array}$ & \multicolumn{2}{|l|}{ No change } \\
\hline SM6 & Specifies strategies to increase participation in school meal programs & \multicolumn{2}{|l|}{ No change } \\
\hline SM7 & Addresses the amount of "seat time" students have to eat school meals & $\begin{array}{l}\text { Wording revised from } 2.0 \text { SM8 to } \\
\text { add "seat time" }\end{array}$ & Feedback from expert survey \\
\hline SM8 & Federal requirement: free drinking water is available during meals & $\begin{array}{l}\text { Wording revised from } 2.0 \mathrm{SM} 14 \text { to } \\
\text { note this is a federal requirement }\end{array}$ & Reflect final rule language \\
\hline SM9 & $\begin{array}{l}\text { Federal requirement: ensures annual training for food and nutrition services } \\
\text { staff in accordance with USDA professional standards }\end{array}$ & \multicolumn{2}{|l|}{ No change } \\
\hline SM10 & $\begin{array}{l}\text { Farm to School item: addresses purchasing local foods for the school meal } \\
\text { program }\end{array}$ & New item & $\begin{array}{l}\text { Feedback from expert survey and } \\
\text { Farm to School best practices }\end{array}$ \\
\hline \multicolumn{4}{|c|}{ Nutrition Standards for Competitive and Other Foods and Beverages (NS) } \\
\hline NS1 & $\begin{array}{l}\text { Federal requirement: assures compliance with USDA nutrition standards } \\
\text { (commonly referred to as Smart Snacks) for all food and beverages sold to } \\
\text { students during the school day }\end{array}$ & $\begin{array}{l}\text { Wording revised from } 2.0 \text { NS1 to } \\
\text { add "assures" }\end{array}$ & Reflect final rule language \\
\hline NS2 & USDA Smart Snack standards are easily accessed in the policy & $\begin{array}{l}\text { Wording revised from } 2.0 \text { NS9 to } \\
\text { say "easily accessed" instead of } \\
\text { requiring standards are described } \\
\text { in full or provided in a link }\end{array}$ & Feedback from expert survey \\
\hline NS3 & Federal requirement: regulates food and beverages sold a la carte & New item & $\begin{array}{l}\text { Venue-specific item to be } \\
\text { consistent with NWPS }\end{array}$ \\
\hline NS4 & Federal requirement: regulates food and beverages sold in vending machines & New item & $\begin{array}{l}\text { Venue-specific item to be } \\
\text { consistent with NWPS }\end{array}$ \\
\hline
\end{tabular}

Abbreviations: CSPAP, comprehensive school physical activity program; HHFKA, Healthy Hunger-Free Kids Act; LEA, Local Education Agency; NWPS, National Wellness Policy Study; USDA, US Department of Agriculture; WPM, wellness promotion and marketing; WellSAT, Wellness School Assessment Tool.

(continued on next page)

The opinions expressed by authors contributing to this journal do not necessarily reflect the opinions of the U.S. Department of Health and Human Services, the Public Health Service, the Centers for Disease Control and Prevention, or the authors' affiliated institutions.

8 Centers for Disease Control and Prevention • www.cdc.gov/pcd/issues/2020/19_0373.htm 
(continued)

Table 2. Final WellSAT 3.0 Items, Removed 2.0 Items, and Reasons for Changes

\begin{tabular}{|c|c|c|c|}
\hline \multicolumn{2}{|c|}{ WelISAT 3.0 Item } & \multirow[b]{2}{*}{ New item } & \multirow{2}{*}{\begin{tabular}{|l|}
\multicolumn{1}{|c}{ Reason for Change } \\
$\begin{array}{l}\text { Venue-specific item to be } \\
\text { consistent with NWPS }\end{array}$ \\
\end{tabular}} \\
\hline NS5 & Federal requirement: regulates food and beverages sold in school stores & & \\
\hline NS6 & Addresses fundraising with food to be consumed during the school day & New item & Reflect final rule language \\
\hline NS7 & Exemptions for infrequent school-sponsored fundraisers & New item & Reflect final rule language \\
\hline NS8 & Addresses foods and beverages containing caffeine at the high school level & \multicolumn{2}{|l|}{ No change } \\
\hline NS9 & $\begin{array}{l}\text { Federal requirement: regulates food and beverages served at class parties } \\
\text { and other school celebrations in elementary schools }\end{array}$ & $\begin{array}{l}\text { Wording revised from } 2.0 \text { NS4 to } \\
\text { combine food and beverages and } \\
\text { indicate it is now a federal } \\
\text { requirement }\end{array}$ & $\begin{array}{l}\text { NWPS data indicate that this issue } \\
\text { is addressed significantly more } \\
\text { frequently in elementary schools } \\
\text { than middle or high schools. } \\
\text { Therefore, this item remains } \\
\text { specific to elementary schools. } \\
\text { However, the federal rule language } \\
\text { is general and does not specify } \\
\text { school level. }\end{array}$ \\
\hline NS10 & $\begin{array}{l}\text { Addresses nutrition standards for all foods and beverages served to students } \\
\text { after the school day, including before/after care on school grounds, clubs, } \\
\text { after-school programming }\end{array}$ & $\begin{array}{l}\text { Wording revised from } 2.0 \text { NS3 to } \\
\text { define "after the school day" to } \\
\text { include clubs and after-school } \\
\text { programming }\end{array}$ & Feedback from expert survey \\
\hline NS11 & $\begin{array}{l}\text { Addresses nutrition standards for all foods and beverages sold to students } \\
\text { after the school day, including before/after care on school grounds, clubs, } \\
\text { after-school programming }\end{array}$ & $\begin{array}{l}\text { Wording revised from } 2.0 \text { NS2 to } \\
\text { combine food and beverages and } \\
\text { include before and aftercare } \\
\text { snacks }\end{array}$ & Feedback from expert survey \\
\hline NS12 & Addresses food not being used as a reward & Moved from WPM subscale & Feedback from expert survey \\
\hline NS13 & Addresses availability of free drinking water throughout the school day & No change & \\
\hline \multicolumn{4}{|c|}{ Physical Education and Physical Activity (PEPA) } \\
\hline PEPA1 & CSPAP: There is a written physical education curriculum for grades $\mathrm{K}-12$. & $\begin{array}{l}\text { Added that this is a component of } \\
\text { CSPAP }\end{array}$ & $\begin{array}{l}\text { Feedback from expert survey to } \\
\text { create separate items for all CSPAP } \\
\text { components }\end{array}$ \\
\hline PEPA2 & $\begin{array}{l}\text { The written physical education curriculum for each grade is aligned with } \\
\text { national and/or state physical education standards }\end{array}$ & Added "for each grade" & Feedback from expert survey \\
\hline PEPA3 & Physical education promotes a physically active lifestyle & New item & $\begin{array}{l}\text { Added because of high frequency } \\
(70 \%) \text { in NWPS and feedback from } \\
\text { expert survey }\end{array}$ \\
\hline PEPA4 & $\begin{array}{l}\text { Addresses time per week of physical education for all elementary school } \\
\text { students }\end{array}$ & \multicolumn{2}{|l|}{ No change } \\
\hline PEPA5 & Addresses time per week of physical education for all middle school students & \multicolumn{2}{|l|}{ No change } \\
\hline PEPA6 & Addresses time per week of physical education for all high school students & \multicolumn{2}{|l|}{ No change } \\
\hline PEPA7 & Addresses qualifications for physical education teachers for grades K-12 & \multicolumn{2}{|l|}{ No change } \\
\hline PEPA8 & $\begin{array}{l}\text { Addresses providing physical education training for physical education } \\
\text { teachers }\end{array}$ & \multicolumn{2}{|l|}{ No change } \\
\hline PEPA9 & Addresses physical education exemption requirements for all students & \multicolumn{2}{|l|}{ No change } \\
\hline PEPA10 & Addresses physical education substitution for all students & \multicolumn{2}{|l|}{ No change } \\
\hline PEPA11 & $\begin{array}{l}\text { CSPAP: Addresses family and community engagement in physical activity } \\
\text { opportunities at all schools }\end{array}$ & $\begin{array}{l}\text { Added that this is a component of } \\
\text { CSPAP }\end{array}$ & $\begin{array}{l}\text { Feedback from expert survey to } \\
\text { create separate items for all CSPAP } \\
\text { components }\end{array}$ \\
\hline PEPA12 & $\begin{array}{l}\text { CSPAP: Addresses before- and after-school physical activity for all students } \\
\text { including clubs, intramural, and interscholastic opportunities }\end{array}$ & $\begin{array}{l}\text { Added that this is a component of } \\
\text { CSPAP }\end{array}$ & $\begin{array}{l}\text { Feedback from expert survey to } \\
\text { create separate items for all CSPAP } \\
\text { components }\end{array}$ \\
\hline
\end{tabular}

Abbreviations: CSPAP, comprehensive school physical activity program; HHFKA, Healthy Hunger-Free Kids Act; LEA, Local Education Agency; NWPS, National Wellness Policy Study; USDA, US Department of Agriculture; WPM, wellness promotion and marketing; WellSAT, Wellness School Assessment Tool.

(continued on next page)

The opinions expressed by authors contributing to this journal do not necessarily reflect the opinions of the U.S. Department of Health and Human Services, the Public Health Service, the Centers for Disease Control and Prevention, or the authors' affiliated institutions. 
(continued)

Table 2. Final WellSAT 3.0 Items, Removed 2.0 Items, and Reasons for Changes

\begin{tabular}{|c|c|c|c|}
\hline \multicolumn{2}{|c|}{ WellSAT 3.0 Item } & \multirow{2}{*}{\begin{tabular}{|l|}
\multicolumn{1}{c}{ Change } \\
Wording revision from 2.0 PEPA15 \\
to include only elementary schools
\end{tabular}} & \multirow{2}{*}{$\begin{array}{r}\text { Reason for Change } \\
\text { To be consistent with NWPS }\end{array}$} \\
\hline PEPA13 & Addresses recess for elementary school students & & \\
\hline PEPA14 & CSPAP: Addresses physical activity breaks for all K-12 students & $\begin{array}{l}\text { Added that this a component of } \\
\text { CSPAP }\end{array}$ & Feedback from expert survey \\
\hline PEPA15 & $\begin{array}{l}\text { Joint or shared-use agreements for physical activity participation at all } \\
\text { schools }\end{array}$ & \multicolumn{2}{|l|}{ No change } \\
\hline PEPA16 & $\begin{array}{l}\text { Addresses active transport (Safe Routes to School) for all K-12 students who } \\
\text { live within walkable/bikeable distance }\end{array}$ & $\begin{array}{l}\text { Wording revised from } 2.0 \text { PEPA13 } \\
\text { to add "Safe Routes to School" }\end{array}$ & Feedback from expert survey \\
\hline \multicolumn{4}{|c|}{ Wellness Promotion and Marketing (WPM) } \\
\hline WPM1 & Encourages staff to model healthy eating and physical activity behaviors & $\begin{array}{l}\text { Wording revised to combine staff } \\
\text { modeling of healthy eating and } \\
\text { physical activity behaviors }\end{array}$ & To be consistent with NWPS \\
\hline WPM2 & CSPAP: Addresses strategies to support employee wellness & $\begin{array}{l}\text { New item to address employee } \\
\text { wellness }\end{array}$ & $\begin{array}{l}\text { To be consistent with NWPS and } \\
\text { feedback from expert survey to } \\
\text { address employee wellness } \\
\text { broadly; also serves as separate } \\
\text { item for staff component of CSPAP }\end{array}$ \\
\hline WPM3 & Addresses using physical activity as a reward & \multicolumn{2}{|l|}{ No change } \\
\hline WPM4 & Addresses physical activity not being used as punishment & \multicolumn{2}{|l|}{ No change } \\
\hline WPM5 & Addresses physical activity not being withheld as punishment & \multicolumn{2}{|l|}{ No change } \\
\hline WPM6 & Specifies marketing to promote healthy food and beverage choices & \multicolumn{2}{|l|}{ No change } \\
\hline WPM7 & $\begin{array}{l}\text { Federal requirement: restricts marketing on the school campus during the } \\
\text { school day to only those foods and beverages that meet Smart Snacks } \\
\text { standards }\end{array}$ & $\begin{array}{l}\text { Wording revised to note that this is } \\
\text { a federal requirement }\end{array}$ & Reflect final rule language \\
\hline WPM8 & $\begin{array}{l}\text { Specifically addresses marketing on school property (eg, signs, scoreboards, } \\
\text { sports equipment) }\end{array}$ & $\begin{array}{l}\text { Wording revised from } 2.0 \text { WPM11 } \\
\text { for clarity }\end{array}$ & Feedback from expert survey \\
\hline WPM9 & $\begin{array}{l}\text { Specifically addresses marketing of educational materials (eg, curricula, } \\
\text { textbooks, or printed or electronic educational materials) }\end{array}$ & $\begin{array}{l}\text { Wording revised from } 2.0 \text { WPM12 } \\
\text { for clarity }\end{array}$ & Feedback from expert survey \\
\hline WPM10 & $\begin{array}{l}\text { Specifically addresses marketing where food is purchased (eg, exteriors of } \\
\text { vending machines, food or beverage cups or containers, food display racks, } \\
\text { coolers, trash and recycling containers) }\end{array}$ & $\begin{array}{l}\text { Wording revised from } 2.0 \text { WPM13 } \\
\text { for clarity }\end{array}$ & Feedback from expert survey \\
\hline WPM11 & $\begin{array}{l}\text { Specifically addresses marketing in school publications and media (eg, } \\
\text { advertisements in school publications, school radio stations, in-school } \\
\text { television, computer screen savers, school-sponsored internet sites, and } \\
\text { announcements on the public announcement [PA] system) }\end{array}$ & $\begin{array}{l}\text { Wording revised from } 2.0 \text { WPM14 } \\
\text { for clarity }\end{array}$ & Feedback from expert survey \\
\hline WPM12 & $\begin{array}{l}\text { Specifically addresses marketing through fundraisers and corporate incentive } \\
\text { programs (eg, fundraising programs that encourage students and their } \\
\text { families to sell, purchase, or consume products and corporate incentive } \\
\text { programs that provide funds to schools in exchange for proof of purchases of } \\
\text { company products such as Box Tops for Education) }\end{array}$ & $\begin{array}{l}\text { Wording revised from } 2.0 \text { WPM15 } \\
\text { and broadened }\end{array}$ & Feedback from expert survey \\
\hline \multicolumn{4}{|c|}{ Implementation, Evaluation, and Communication (IEC) } \\
\hline IEC1 & Addresses the establishment of an ongoing district wellness committee & \multicolumn{2}{|l|}{ No change } \\
\hline IEC2 & $\begin{array}{l}\text { Federal requirement: addresses how all relevant stakeholders (parents, } \\
\text { students, representatives of the school food authority, teachers of physical } \\
\text { education, school health professionals, the school board, school } \\
\text { administrator, and the general public) will participate in the development, } \\
\text { implementation, and periodic review and update of the local wellness policy }\end{array}$ & $\begin{array}{l}\text { Wording revised to note this is a } \\
\text { federal requirement }\end{array}$ & Reflect final rule language \\
\hline IEC3 & $\begin{array}{l}\text { Federal requirement: identifies the officials responsible for the } \\
\text { implementation of and compliance with the local wellness policy }\end{array}$ & $\begin{array}{l}\text { Wording revised to note this is a } \\
\text { federal requirement }\end{array}$ & Reflect final rule language \\
\hline
\end{tabular}

Abbreviations: CSPAP, comprehensive school physical activity program; HHFKA, Healthy Hunger-Free Kids Act; LEA, Local Education Agency; NWPS, National Wellness Policy Study; USDA, US Department of Agriculture; WPM, wellness promotion and marketing; WellSAT, Wellness School Assessment Tool. 
(continued)

Table 2. Final WellSAT 3.0 Items, Removed 2.0 Items, and Reasons for Changes

\begin{tabular}{|c|c|c|c|}
\hline \multicolumn{2}{|c|}{ WellSAT 3.0 Item } & \multirow{2}{*}{\begin{tabular}{|l}
\multicolumn{1}{c}{ Change } \\
$\begin{array}{l}\text { Updated from } 2.0 \text { IEC5 to reflect } \\
\text { federal requirement }\end{array}$
\end{tabular}} & \multirow{2}{*}{\begin{tabular}{|l|} 
Reason for Change \\
Reflect final rule language
\end{tabular}} \\
\hline IEC4 & $\begin{array}{l}\text { Federal requirement: addresses making the wellness policy available to the } \\
\text { public annually }\end{array}$ & & \\
\hline IEC5 & $\begin{array}{l}\text { Federal requirement. addresses the assessment of district implementation of } \\
\text { the local wellness policy at least once every } 3 \text { years }\end{array}$ & $\begin{array}{l}\text { Updated from } 2.0 \text { IEC5 to reflect } \\
\text { triennial assessment }\end{array}$ & Reflect final rule language \\
\hline IEC6 & $\begin{array}{l}\text { Triennial assessment results will be made available to the public and will } \\
\text { include } \\
\text { the extent to which schools under the jurisdiction of the LEA are in } \\
\text { compliance with the local school wellness policy } \\
\text { the extent to which the LEA's local school wellness policy compares to model } \\
\text { local school wellness policies; and } \\
\text { the description of the progress made in attaining the goals of the local school } \\
\text { wellness policy. }\end{array}$ & $\begin{array}{l}\text { Updated from } 2.0 \text { IEC7 to include } \\
\text { the specific components in the } \\
\text { federal requirement }\end{array}$ & Reflect final rule language \\
\hline IEC7 & $\begin{array}{l}\text { Federal requirement: addresses a plan for updating the policy based on } \\
\text { results of the triennial assessment }\end{array}$ & $\begin{array}{l}\text { Wording revised from } 2.0 \text { IEC9 to } \\
\text { note this is a federal requirement } \\
\text { based on the triennial assessment }\end{array}$ & Reflect final rule language \\
\hline IEC8 & $\begin{array}{l}\text { Addresses the establishment of an ongoing school building-level wellness } \\
\text { committee. }\end{array}$ & New item & $\begin{array}{l}\text { Feedback from expert survey and } \\
\text { best practice (21) }\end{array}$ \\
\hline \multicolumn{4}{|c|}{ Former WellSAT 2.0 Item } \\
\hline $2.0 \mathrm{SM} 3$ & $\begin{array}{l}\text { School meals meet standards that are more stringent than those required by } \\
\text { USDA }\end{array}$ & Removed & $\begin{array}{l}\text { Unnecessary due to updated USDA } \\
\text { standards per HHFKA }\end{array}$ \\
\hline $2.0 \mathrm{SM} 7$ & Addresses students leaving school during lunch periods & Removed & Low frequency $(6 \%)$ in NWPS data \\
\hline $2.0 \mathrm{SM} 10$ & Addresses school meal environment & Removed & $\begin{array}{l}\text { Lack of specificity and } \\
\text { interpretability }\end{array}$ \\
\hline $2.0 \mathrm{SM} 11$ & $\begin{array}{l}\text { Nutrition information for school meals (eg, calories, saturated fat, sodium, } \\
\text { sugar) is available to students and parents }\end{array}$ & Removed & $\begin{array}{l}\text { Unnecessary due to updated USDA } \\
\text { standards per HHFKA }\end{array}$ \\
\hline $2.0 \mathrm{SM} 13$ & Recess (when offered) is scheduled before lunch in elementary schools & Removed & $\begin{array}{l}\text { Lack of empirical support }(22,23) \\
\text { and concerns about feasibility from } \\
\text { experts }\end{array}$ \\
\hline $2.0 \mathrm{NS} 7$ & $\begin{array}{l}\text { Addresses foods and beverages containing non-nutritive sweeteners (High } \\
\text { School) }\end{array}$ & Removed & $\begin{array}{l}\text { Low frequency in NWPS data set } \\
\text { (4\% for food, } 10 \% \text { for beverages) } \\
\text { and current scientific guidance (24) }\end{array}$ \\
\hline 2.0 PEPA6 & Addresses teacher:student ratio for physical education classes & Removed & $\begin{array}{l}\text { Low frequency (15\%) in NWPS data } \\
\text { set }\end{array}$ \\
\hline 2.0 PEPA9 & Addresses physical education waiver requirements for K-12 students & Removed & $\begin{array}{l}\text { Low frequency }(10 \%) \text { and because } \\
\text { this occurs at state, not district } \\
\text { level }\end{array}$ \\
\hline $\begin{array}{l}2.0 \\
\text { PEPA12 }\end{array}$ & District addresses the development of a CSPAP plan at each school & Removed & $\begin{array}{l}\text { Removed because CSPAP } \\
\text { components are now separated } \\
\text { and noted for each relevant item }\end{array}$ \\
\hline $\begin{array}{l}2.0 \\
\text { PEPA17 }\end{array}$ & Addresses staff involvement in physical activity opportunities at all schools & Removed & $\begin{array}{l}\text { Low frequency (18\%). Expert } \\
\text { feedback to address staff wellness } \\
\text { broadly. NWPS variable on staff } \\
\text { wellness added instead (3.0 } \\
\text { WPM2) }\end{array}$ \\
\hline $\begin{array}{l}2.0 \\
\text { PEPA19 }\end{array}$ & District provides physical activity training for all teachers & Removed & For consistency with NWPS \\
\hline 2.0 WPM1 & Addresses staff not modeling unhealthy eating/drinking behaviors & Removed & $\begin{array}{l}\text { For consistency with NWPS Positive } \\
\text { staff role modeling is addressed in } \\
\text { 3.0 WPM1 }\end{array}$ \\
\hline
\end{tabular}

Abbreviations: CSPAP, comprehensive school physical activity program; HHFKA, Healthy Hunger-Free Kids Act; LEA, Local Education Agency; NWPS, National Wellness Policy Study; USDA, US Department of Agriculture; WPM, wellness promotion and marketing; WellSAT, Wellness School Assessment Tool.

The opinions expressed by authors contributing to this journal do not necessarily reflect the opinions of the U.S. Department of Health and Human Services, the Public Health Service, the Centers for Disease Control and Prevention, or the authors' affiliated institutions. 
Table 3. Distribution of WellSAT 3.0 Coding of No, Weak, or Strong Policy Language and Mean Comprehensiveness and Strength Scores ${ }^{a}$

\begin{tabular}{|c|c|c|c|c|}
\hline \multirow[b]{2}{*}{ WellSAT 3.0 Variable Category } & \multicolumn{3}{|c|}{ No. $(\%)$ of Districts $(N=50)$} & \multirow{2}{*}{$\begin{array}{l}\text { Mean Score } \\
\text { (SD) }\end{array}$} \\
\hline & No Policy $=0$ & Weak Policy = 1 & Strong Policy $=2$ & \\
\hline \multicolumn{5}{|l|}{ NE: mean comprehensiveness $=74 ;$ mean strength $=55$} \\
\hline NE1. Goals for nutrition education ${ }^{b}$ & $1(2)$ & $2(4)$ & $47(94)$ & $1.92(0.34)$ \\
\hline NE2. Nutrition education teaches behavior-focused skills & $7(14)$ & $3(6)$ & $40(80)$ & $1.66(0.72)$ \\
\hline NE3. Elementary school nutrition education & $4(8)$ & $15(30)$ & $31(62)$ & $1.54(0.65)$ \\
\hline NE4. Middle school nutrition education & $4(8)$ & $15(30)$ & $31(62)$ & $1.54(0.65)$ \\
\hline NE5. High school nutrition education ${ }^{c}$ & $5(11)$ & $14(31)$ & $26(58)$ & $1.47(0.69)$ \\
\hline NE6. Nutrition education integrated into other subjects & $22(44)$ & $9(18)$ & $19(38)$ & $0.94(0.91)$ \\
\hline NE7. Links nutrition education with school food environment & $23(46)$ & $11(22)$ & $16(32)$ & $0.86(0.88)$ \\
\hline NE8. Nutrition education addresses agriculture and the food system & $36(72)$ & $9(18)$ & $5(10)$ & $0.38(0.67)$ \\
\hline
\end{tabular}

\section{Standards for USDA Child Nutrition Programs and SM: mean comprehensiveness $=53$; mean strength $=27$}

\begin{tabular}{|c|c|c|c|c|}
\hline SM1. USDA school meals ${ }^{b}$ & $4(8)$ & $42(84)$ & $4(8)$ & $1.00(0.40)$ \\
\hline SM2. USDA School Breakfast Program & $11(22)$ & $18(36)$ & $21(42)$ & $1.20(0.78)$ \\
\hline SM3. Protects privacy of students ${ }^{b}$ & $24(48)$ & $9(18)$ & $17(34)$ & $0.86(0.90)$ \\
\hline SM4. Unpaid meal charges & $44(88)$ & $3(6)$ & $3(6)$ & $0.18(0.52)$ \\
\hline SM5. Eligibility information & $23(46)$ & $7(14)$ & $20(40)$ & $0.94(0.93)$ \\
\hline SM6. Strategies to increase participation & $13(26)$ & $9(18)$ & $28(56)$ & $1.30(0.86)$ \\
\hline SM7. Seat time for lunch & $24(48)$ & $21(42)$ & $5(10)$ & $0.62(0.67)$ \\
\hline SM8. Water during meals ${ }^{b}$ & $26(52)$ & $1(2)$ & $23(46)$ & $0.94(1.00)$ \\
\hline SM9. Food service training ${ }^{b}$ & $23(46)$ & $20(40)$ & $7(14)$ & $0.68(0.71)$ \\
\hline SM10. Local food procurement & $41(82)$ & $2(4)$ & 7 (14) & $0.32(0.71)$ \\
\hline
\end{tabular}

NS for competitive and other foods and beverages: mean comprehensiveness $=59 ;$ mean strength $=37$

\begin{tabular}{|c|c|c|c|c|}
\hline NS1. Smart Snacks ${ }^{b}$ & $1(2)$ & $9(18)$ & $40(80)$ & $1.78(0.46)$ \\
\hline NS2. Link to or full text of Smart Snacks & $8(16)$ & $33(66)$ & $9(18)$ & $1.02(0.59)$ \\
\hline NS3. A la carte sales ${ }^{b}$ & $3(6)$ & $7(14)$ & $40(80)$ & $1.74(0.56)$ \\
\hline NS4. Vending machine sales ${ }^{b}$ & $2(4)$ & 7 (14) & $41(82)$ & $1.78(0.51)$ \\
\hline NS5. School store sales ${ }^{b}$ & $3(6)$ & $7(14)$ & $40(80)$ & $1.74(0.56)$ \\
\hline NS6. Fundraisers ${ }^{\mathrm{b}}$ & $0(0)$ & $8(16)$ & $42(84)$ & $1.84(0.37)$ \\
\hline NS7. Exemptions for infrequent school-sponsored fundraisers & $38(76)$ & $10(20)$ & $2(4)$ & $0.28(0.54)$ \\
\hline NS8. Caffeine high school ${ }^{\mathrm{C}}$ & $44(98)$ & $1(2)$ & $0(0)$ & $0.02(0.15)$ \\
\hline NS9. Elementary school class parties ${ }^{\text {b }}$ & $17(34)$ & $33(66)$ & $0(0)$ & $0.66(0.48)$ \\
\hline NS10. Food served before/after school day & $44(88)$ & $3(6)$ & $3(6)$ & $0.18(0.52)$ \\
\hline NS11. Food sold after school day & $43(86)$ & $6(12)$ & $1(2)$ & $0.16(0.42)$ \\
\hline NS12. Food as reward & $23(46)$ & $20(40)$ & $7(14)$ & $0.68(0.71)$ \\
\hline NS13. Water throughout day & $36(72)$ & $0(0)$ & $14(28)$ & $0.56(0.91)$ \\
\hline
\end{tabular}

PEPA: mean comprehensiveness $=49 ;$ mean strength $=28$

Abbreviations: IEC, Implementation, Evaluation, and Communication; NE, Nutrition Education; SM, Standards for USDA School Meals; NS, Nutrition Standards for Competitive and Other Foods and Beverages; PA, physical activity; PE, physical education; PEPA, Physical Education and Physical Activity; SD, standard deviation; USDA, US Department of Agriculture; WellSAT, Wellness School Assessment Tool; WPM, Wellness Promotion and Marketing.

${ }^{\mathrm{a}}$ Mean overall comprehensiveness score $=54$; mean overall strength score $=33$.

${ }^{\mathrm{b}}$ This item is reflected in the Federal Rule.

${ }^{c}$ Fewer than 50 districts were scored for high school items because some districts in the sample did not contain any high schools. 
(continued)

Table 3. Distribution of WellSAT 3.0 Coding of No, Weak, or Strong Policy Language and Mean Comprehensiveness and Strength Scores ${ }^{a}$

\begin{tabular}{|c|c|c|c|c|}
\hline \multirow[b]{2}{*}{ WellSAT 3.0 Variable Category } & \multicolumn{3}{|c|}{ No. (\%) of Districts $(\mathrm{N}=50)$} & \multirow{2}{*}{$\begin{array}{l}\text { Mean Score } \\
\text { (SD) }\end{array}$} \\
\hline & No Policy $=0$ & Weak Policy = 1 & Strong Policy $=2$ & \\
\hline PEPA1. PE curriculum & $0(0)$ & $7(14)$ & $43(86)$ & $1.86(0.35)$ \\
\hline PEPA2. National or state PE standards & $9(18)$ & $2(4)$ & $39(78)$ & $1.60(0.78)$ \\
\hline PEPA3. Physically active lifestyle & $7(14)$ & $2(4)$ & $41(82)$ & $1.68(0.71)$ \\
\hline PEPA4. PE time elementary school & $31(62)$ & $16(32)$ & $3(6)$ & $0.44(0.61)$ \\
\hline PEPA5. PE time middle school & $33(66)$ & $16(32)$ & $1(2)$ & $0.36(0.53)$ \\
\hline PEPA6. PE time high school ${ }^{\mathrm{C}}$ & $40(89)$ & $4(9)$ & $1(2)$ & $0.13(0.40)$ \\
\hline PEPA7. Qualifications for PE teachers & $25(50)$ & $4(8)$ & $21(42)$ & $0.92(0.97)$ \\
\hline PEPA8. PE teacher training & $32(64)$ & $5(10)$ & $13(26)$ & $0.62(0.88)$ \\
\hline PEPA9. PE exemption & $48(96)$ & $2(4)$ & $0(0)$ & $0.04(0.20)$ \\
\hline PEPA10. PE substitution & $47(94)$ & $1(2)$ & $2(4)$ & $0.10(0.42)$ \\
\hline PEPA11. Family engagement in PA & $22(44)$ & $24(48)$ & $4(8)$ & $0.64(0.63)$ \\
\hline PEPA12. Before/after school PA opportunities & $11(22)$ & $18(36)$ & $21(42)$ & $1.20(0.78)$ \\
\hline PEPA13. Recess & $19(38)$ & $25(50)$ & $6(12)$ & $0.74(0.66)$ \\
\hline PEPA14. PA breaks & $14(28)$ & $30(60)$ & $6(12)$ & $0.84(0.62)$ \\
\hline PEPA15. Joint use & $33(66)$ & $6(12)$ & $11(22)$ & $0.56(0.84)$ \\
\hline PEPA16. Safe Routes to School & $33(66)$ & $8(16)$ & $9(18)$ & $0.52(0.79)$ \\
\hline \multicolumn{5}{|l|}{ WPM: mean comprehensiveness $=32 ;$ mean strength $=20$} \\
\hline WPM1. Staff role model & $21(42)$ & $20(40)$ & $9(18)$ & $0.76(0.74)$ \\
\hline WPM2. Employee wellness & $27(54)$ & $6(12)$ & $17(34)$ & $0.80(0.93)$ \\
\hline WPM3. PA as reward & $48(96)$ & $0(0)$ & $2(4)$ & $0.08(0.40)$ \\
\hline WPM4. PA as punishment & $28(56)$ & $8(16)$ & $14(28)$ & $0.72(0.88)$ \\
\hline WPM5. PA withheld as punishment & $29(58)$ & $7(14)$ & $14(28)$ & $0.70(0.89)$ \\
\hline WPM6. Healthy marketing & $22(44)$ & $4(8)$ & $24(48)$ & $1.04(0.97)$ \\
\hline WPM7. Restricted marketing ${ }^{b}$ & $23(46)$ & $7(14)$ & $20(40)$ & $0.94(0.93)$ \\
\hline WPM8. Marketing on signs & $42(84)$ & $4(8)$ & $4(8)$ & $0.24(0.59)$ \\
\hline WPM9. Marketing in education materials & $42(84)$ & $4(8)$ & $4(8)$ & $0.24(0.59)$ \\
\hline WPM10. Marketing on vending machines & $42(84)$ & $4(8)$ & $4(8)$ & $0.24(0.59)$ \\
\hline WPM11. Marketing in school publications/radio channel 1 & $42(84)$ & $4(8)$ & $4(8)$ & $0.24(0.59)$ \\
\hline WPM12. Marketing through fundraisers & $44(88)$ & $3(6)$ & $3(6)$ & $0.18(0.52)$ \\
\hline \multicolumn{5}{|l|}{ IEC: mean comprehensiveness $=70$; mean strength $=47$} \\
\hline IEC1. District committee & $8(16)$ & $6(12)$ & $36(72)$ & $1.56(0.76)$ \\
\hline IEC2. Stakeholders $^{\mathrm{b}}$ & $6(12)$ & $24(48)$ & $20(40)$ & $1.28(0.67)$ \\
\hline IEC3. Identifies person responsible ${ }^{b}$ & 9 (18) & $7(14)$ & $34(68)$ & $1.50(0.79)$ \\
\hline
\end{tabular}

Abbreviations: IEC, Implementation, Evaluation, and Communication; NE, Nutrition Education; SM, Standards for USDA School Meals; NS, Nutrition Standards for Competitive and Other Foods and Beverages; PA, physical activity; PE, physical education; PEPA, Physical Education and Physical Activity; SD, standard deviation; USDA, US Department of Agriculture; WellSAT, Wellness School Assessment Tool; WPM, Wellness Promotion and Marketing.

${ }^{\text {a }}$ Mean overall comprehensiveness score $=54$; mean overall strength score $=33$.

${ }^{\mathrm{b}}$ This item is reflected in the Federal Rule.

${ }^{c}$ Fewer than 50 districts were scored for high school items because some districts in the sample did not contain any high schools. 


\section{PREVENTING CHRONIC DISEASE}

VOLUME 17, E52

PUBLIC HEALTH RESEARCH, PRACTICE, AND POLICY

JULY 2020

(continued)

Table 3. Distribution of WellSAT 3.0 Coding of No, Weak, or Strong Policy Language and Mean Comprehensiveness and Strength Scores ${ }^{a}$

\begin{tabular}{|c|c|c|c|c|}
\hline \multirow[b]{2}{*}{ WellSAT 3.0 Variable Category } & \multicolumn{3}{|c|}{ No. $(\%)$ of Districts $(\mathrm{N}=50)$} & \multirow{2}{*}{$\begin{array}{l}\text { Mean Score } \\
\text { (SD) }\end{array}$} \\
\hline & No Policy $=0$ & Weak Policy = 1 & Strong Policy $=2$ & \\
\hline IEC4. Wellness policy available ${ }^{b}$ & $23(46)$ & $6(12)$ & $21(42)$ & $0.96(0.95)$ \\
\hline IEC5. Triennial assessment ${ }^{b}$ & $6(12)$ & $9(18)$ & $35(70)$ & $1.58(0.70)$ \\
\hline IEC6. Triennial assessment made available ${ }^{\mathrm{b}}$ & $17(34)$ & $15(30)$ & $18(36)$ & $1.02(0.84)$ \\
\hline IEC7. Update ${ }^{\mathrm{b}}$ & $8(16)$ & $24(48)$ & $18(36)$ & $1.20(0.70)$ \\
\hline IEC8. School committee & $44(88)$ & $1(2)$ & $5(10)$ & $0.22(0.62)$ \\
\hline
\end{tabular}

Abbreviations: IEC, Implementation, Evaluation, and Communication; NE, Nutrition Education; SM, Standards for USDA School Meals; NS, Nutrition Standards for Competitive and Other Foods and Beverages; PA, physical activity; PE, physical education; PEPA, Physical Education and Physical Activity; SD, standard deviation; USDA, US Department of Agriculture; WellSAT, Wellness School Assessment Tool; WPM, Wellness Promotion and Marketing.

${ }^{a}$ Mean overall comprehensiveness score $=54$; mean overall strength score $=33$.

${ }^{\mathrm{b}}$ This item is reflected in the Federal Rule.

${ }^{\mathrm{c}}$ Fewer than 50 districts were scored for high school items because some districts in the sample did not contain any high schools.

The opinions expressed by authors contributing to this journal do not necessarily reflect the opinions of the U.S. Department of Health and Human Services, the Public Health Service, the Centers for Disease Control and Prevention, or the authors' affiliated institutions. 